\title{
KFOR MISSION IN KOSOVO AND ITS FUTURE
}

\author{
Shaip OSMANI \\ PhD.c Tirana Armed Forces Academy
}

\section{DOI:10.5901/mjss.2014.v5n19p350}

\begin{abstract}
:
What was the role of KFOR intervention in the past in Kosovo, what were KFOR competences with regards to Kosovo as compared the mistakes these missions have made in Bosnia and Herzegovina? What were the difficulties of this mission in Kosovo as the mission was for the very first time under NATO command? What were the outcomes of KFOR in the field, after its installation? Is the presence of KFOR still necessary to provide security in the territory of Kosovo, and what is its role in cooperating with Kosovo and international institutions to support the security institutions of Kosovo? Where does KFOR still continues to have a positive impact in Kosovo, to help further in the stability of situation? What are its projects in the future? What are the focuses of a calm and secured environment in Kosovo? One thing must be clear; Kosovo still needs the KFOR mission to continue its support and contribution in Kosovo attempts to maintain the democratic principles, to build a transparent society and to maintain a calm and secured environment in those parts of Kosovo, where more than one Kosovar entity lives. This mission will be a direct push forward and a guarantee for the Euro-Atlantic future of Kosovo, and it will be a continuous need for a certain period of time to establish the order as well as to assist in the important issues in Kosovo up to the final processes to integrate in NATO. The presence of this mission will be necessary in middle-terms to provide advice in the security sector towards Euro-Atlantic standards.
\end{abstract}

Key words: KFOR mission, Kosovo, objectives, preventions, developments and the future.

The capitulation of Yugoslavia on 10 June 1999 opened the way for the installation of NATO troops in Kosovo. The very first KFOR components entered Kosovo on 12 June 1999. As agreed by the Military Technical Agreement, the dislocation of KFOR forces was synchronized by the getaway of the Serbian forces from Kosovo. On 20 June, the Serbian forces were withdrawn from Kosovo, while KFOR achieved its initial task of dislocation. Moreover, on 20 June after the confirmation of Supreme Commander of Alliance forces for Europe (SACEUR) the Serbian Forces left Kosovo, the secretary of NATO, in compliance with the Military Technical Agreement, from Alliance declared the closure of air campaign. The KFOR full capacity consisted of 50.000 personnel. KFOR consisted of all 19 Member Countries as well as 20 others outside NATO, though; all of these forces came under the command and unified control of KFOR.

On 10 June, the responsibilities of International Committee were specified during the internal administration of Kosovo through the United Nations Security Council Resolution 1244. The resolution and the Military Technical Agreement for the withdrawal of Yugoslavian Forces as well as NATO operational plan 10413 (the operation joint protection) compose the basic responsibilities of KFOR in Kosovo. The resolution is completely tied with the security issue, which derives from the Security Council mandate for "Maintenance of International Peace and Security", based on Annex 2 of the Resolution. In addition to KFOR, the presence of UNMIK Police was enabled, as it was supposed to be reached the international security presence parallel to substantial presence of NATO, under a single command and control, authorized to create a secured environment for the entire population of Kosovo and to enable the safe return of the dislocated people and refugees" 1. After the installation of KFOR forces and UNMIK Police, it started the establishment of a new security environment, based on contemporary concepts of establishing security services. The dislocation of the first international forces in Kosovo started on 10 of June. Russia started the transferring of its troops in Kosovo, 2 yet the contingent of the first NATO troops under the KFOR mission entered Kosovo on 11 June 1999. After a week the number of KFOR troops reached 15.000, while by the end of June the number of troops reached 23.000 , and finally by the end of July the number of troops reached 34.000 . However, KFOR managed to get structured according to the action plan by the end of this year 3 . According to the agreement on withdrawal pace, in June 20th, the Yugoslavian Military- Police Forces took completely away from Kosovo.

\footnotetext{
1 UNSC Resolution 1244, Annex 2

2 Wesley K. Clark, Waging Modern War, Bosnia, Kosovo, and the Future of Combat Daily "Zëri" Prishtinë 2003, p.421.

${ }^{3}$ Martti Ahttisari, Duties in Belgrade, Pristine 2008
} 
After a long discussion between NATO and Russia on 7 July, both parties concluded an agreement for the role and responsibilities of the Russian soldiers under the international mission.

The process of demilitarization of KLA began on 9 July 1999, this process was managed by KFOR, and the handing over of the heavy weapons according to the agreement, began by KLA in the middle of July and ended within this month.

KFOR began its mission by supporting the refugees and dislocated people to return home, by creating a common security environment, protecting ethnic minorities, securing religious sites, securing the border, banning the contraband at borders, implementing a weapon amnesty program, ammunition and explosives for the whole territory of Kosovo, destruction of weapons and supporting the establishment of civil institutions, laws and regulations, judicial and criminal system, election processes and in other respects in political, economical and societal life1.

The Peacekeeping mission in Kosovo consisted of different nations of the Euro-Atlantic Alliance not only this but also, the other partner states of this Alliance, provided an understanding demonstration and a coordination of duties to achieve a goal. KFOR and the soldiers of international community have cleaned over 16.000 houses, 1165 schools and around 2000 kilometers of roads of ammunitions and unexploded mines. Further, over 43.000 Kosovo Albanians have been offered medical services within KFOR centers. On the other hand, a lot of people may remember as a barrier the distinctions in our past history, culture, tradition, language or religion, but these should not be as a barrier of our unity for a common organization. As this example was demonstrated by NATO, through its mission KFOR, which has supported and continues to support the establishment of a long standing peace, the establishment of democratic institutions, the creation of interethnic trust and provides a common future for the whole nationals of Kosovo. The values of NATO are present and are being implemented; moreover, Kosovo is an example of presenting the values and NATO efforts to convert these values as the common values of the country. KFOR has continuously supported through activities such as KOSOVISION, which was a mission supporting the Kosovar Society in general, especially supporting communities through building new schools, cultural centers, ambulances, roads and other civil sites. NATO has provided and continues to support in an extraordinary manner the establishment of security institutions in our country, especially supporting the Kosovo Defense Troops, and now is supporting the establishment of Kosovo Security Forces. KFOR has independent competences in the security sector, aiming not to repeat the mistakes conduced in Bosnia, where the civil sector did not have the required capacity for intervention, whereas the Military component could not grab the intervention mandate without the consent of the civil sector.

In the support of KFOR, in terms of cooperation with civil sectors was the component for (Civil-Military Cooperation) within KFOR. "Effective Cooperation Enlarges the Use of Military and Humanitarian assets; further, it enlarges the security of troops and facilitates the quicker transfer of responsibilities to civil authorities"2

The challenges for KFOR were huge, especially at the installation of the international administration, after a large number of the returned refugees, on providing shelter for refugees, providing security, which became a 'big recursive phenomenon against ethnic minorities such as revenge against earlier suffering of the major population" 3 , and the demolished infrastructure.

KFOR had to care of everything until the administration of UNMIK and Kosovo structures started working. Even currently, KFOR continues to care for the security of the international community in Kosovo, the reforms on protection, foreign defense, the security of religious sites (that almost passed under the Security of Kosovo Police), as well as supporting Kosovo Police when needed. KFOR is largely engaged in the professionalization of Kosovo Security Forces and its civil oversight. KFOR supported Kosovo Security Forces in monitoring and counseling to achieve its full operational capacity and has supported to become fully capable to perform the assigned duties within its mandate, according to the standards specified by NATO. Furthermore, KFOR continues to provide support and advice to Kosovo Security Forces, through a liaison and a consultant team of NATO. KFOR is now focused to provide a secured environment, in those parts of Kosovo where more than one Kosovar ethnicity lives, aiming to secure peace. As such, KFOR cooperates with local and international bodies to build a peaceful environment. This mission remains unchanged; therefore this mission is to provide a secured environment for the whole people and communities in Kosovo, KFOR, continues to conduct this mission in compliance with the mandate of the United Nations.

\footnotetext{
1 http://www.nato.int/kfor/.com

2 Thomas R. Mockaitis, Civil-Military Cooperation in Peace Operations: The Case of Kosovo, October 2004, Strategic Studies Institute Hom. http://www.carlise.arm.mil/ssi/

3 OSCE Mission in Kosovo, Kosovo/Kosova-As Seen, As Told. A Report on the Human Rights Findings of the OSCE Mission in Kosovo June to October 1999 (Prishtina: OSCE Mission in Kosovo 1999)
} 
We may say that from 1999 onwards, that KFOR has played a key role in securing peace, stability and security in Kosovo. However, UNMIK was dealing with issues of legal, economical and societal administration, and if OSCE managed the election and the installation of a democratic system, and if EU contributed to a rapid curing of war damages and injuries. KFOR played a key role in creating a secured environment for the implementation of other policies in Kosovo. In addition, KFOR remains less or not at all opposed by the majority of population of Kosovo, primarily by Kosovo Albanians. This mission is perceived and assessed not only as a peace and security mission, but as a liberation military force for the inhabitants of the territory of Kosovo.

While, the capacity of KFOR to foresee the violence, to locate troops and react adequately was confirmed in March 2004, when KFOR showed that it was an important factor to prevent violence, in addition, the history of KFOR in itself has played an important role in its engagement with communities. Further, even though KFOR mission was not to improve the interethnic relations, it became clear that KFOR was the prior moving force as an accelerant and supporter of interethnic activities. KFOR Mission does not include the promotion of positive interethnic relations, however quite a lot of people consider KFOR among the most important factors for establishment of peace1. The peacekeeping contingent of KFOR reduced drastically in 2010, now only 10 thousand troops remained compared to 1999, where 50 thousand troops were installed in Kosov02. Referring to some security experts, we assess that the reduction of peacekeeping troops in Kosovo has come due to the establishment of a long standing security situation as well as due to the strengthening of Kosovo Security Forces itself, such as Police, Special Unit of Police, Kosovo Security Forces which is trained and supported logistically from NATO itself, etc. This anticipation has come from many factors, the most important and the most communicative one for this issue is "the failure of many exaggerated anticipations for revenge in Kosovo". However, Kosovo according to foreign politicians and diplomats now is a "state model" for "peaceful and democratic coexistence". Craig Whitlock wrote on "Washington Post" on 1 December 2009 textually this "Regardless of its problems and hurts increasing, Kosovo has been referenced by lots of diplomats as a trustworthy model of a state building.

But, the presence of a such a large number of military forces, from which Germany dominates with the largest number of forces present in Kosovo, proves that Kosovo even after all these Security Factors, still needs KFOR to stay in Kosovo as it is considered that the conflict hasn't ended yet. To offer some arguments that the conflict has not ended yet and that NATO remains the key factor of keeping balanced peace and stability in Kosovo, we will discuss two important moments of security in Kosovo: the first moment has to do with the period of March 2004. At this time, Kosovo experienced a wide conflict between Kosovo Albanians and Serbs located in its entire territory. The events occurred and run rapidly on 17 and 18 March 2004, nevertheless, some signals for an interethnic conflict between Kosovo Albanians and Serbs were seen even earlier. In particular, on 17/18 March a wide spread of interethnic riots emerged throughout all dwellings. In these riots was assumed to have participated around 50 thousand protesters, this occurred due to a news on TV on 16th of March, where two children were drown on Iber river, because of some Serbs that killed these Kosovo Albanian children in the river in Mitrovica North. This was the last moment and an ample cause that led into a protest and ethnic confront in Kosovo, the riots spread all over Kosovo. The most tensioned area was Motrovica as both parties Kosovo Albanians in the South and Serbs in the North settled barricades of confronts among them 3. During these riots 21 civilians lost their lives and 1100 others wounded. Churches, Mosques and Monasteries were fired4. KFOR was criticized by different structures for its incapability to prevent these events and for lack action. However, the violent react of thousands of people strongly mobilized in protests against continuous provocations of Serbia in Kosovo was disabled. These riots were led by a large number of factors: On 16 February, the Kosovo Police in cooperation with UNMIK Police arrested some officials of Kosovo Defense Troops, former Soldiers of Kosovo Liberation Army under charges for war crimes. On 27 February began the process of Hague for the Former Senior Members of KLA, the Serbian prosecution announced the warrant arrest for Hashim Thaçi and Agim Çeku, while the mission of UNMIK instead of performing its mission for the administration of Kosovo, was directed by Serbia in some cases, especially in the privatization process, whereas the European Union and the Contact Group had declared their platform "Standards before Status" yet, another proposal came from Belgrade for the Canonization of Kosovo. In addition, the high scale of unemployment, the lack of economic development, the blockage of investments and privatization by UNMIK forced Kosovo Albanians to emerge. In this case only KFOR became a single force unbiased by

\footnotetext{
${ }^{1}$ Has the establishment of Peace Brought change in Kosovo, a study on efficiency of Peace Establishment to Prevent Violence : Lessons learnt from March 2004 riots in Kosovo, the Project for Joint Learning of CDA, July 2006UNSC Resolution 1244, Annex 2. ${ }^{2}$ Htpp://www.kosovonews.de/669/kfor

${ }^{3}$ Enver Bytyqi, The imposing Diplomacy of NATO in Kosovo, The Institute of South East European Studies in Tirana, Tirana 2012 ${ }^{4}$ Bernhard Chiari: Zuruck in den Krieg? Die Unruhen vom Marz 2004, In: Wegweiser zur Geschichte-Kosovo, Herausgegen vom Militargeschichtlichen Forschungsamt, 2006,seite107
} 
Kosovo Albanians. The second moment is in particular connected to the period right after the declaration of independence, because the government of Belgrade acted in Mitrovica North, with a lot of tools to hinder the settlement of Kosovo institutions Authority. Though, this part of Kosovo has been not controlled by Kosovo institutions since 1999, this area was directed by the parallel institutions of Serbia since then; this part was directed directly from Serbia even though KFOR had its troops there.

After the declaration of the Independence of Kosovo a hundreds of Serbs came from the territory of Serbia in March 2008 and burned out all border Crossing Points with Kosovo. Since then, the north of Mitrovica remains out of every control and as a consequence the contraband and goods trafficking, organized crime emerged, considering these occurrences the legal state of Kosovo as well as KFOR were endangered, especially KFOR, in the security respects. Observing contraband, organized crime in the north of Mitrovica which was a classic anarchy, Kosovo Police on 15 July 2011, took under control two border crossing points in the North.

From this moment onwards, KFOR faced with a new type of violence performed by Serbian community living in the north of Mitrovica, while the Kosovo Albanians and Bosnians were under pressure, furthermore, the police border check points and customs check points were burned. Serbia installed many barricades on roads; with these barricades they blocked the movement of vehicles and goods, and created serious difficulties. The KFOR troops were forced to react for the de blocking of the situation, but Serbian protesters used their arms several times, Molotov cocktails and stones against NATO soldiers, wounding tens of them 1. In this confrontation between Serbian protesters and KFOR forces many soldiers of NATO were wounded. In order to cope with this violent situation and blockage of the Serbian Barricades, NATO decided to raise the number of troops in this country, where Germany sent 5 hundred additional troops increasing its contribution for the stability and peace in Kosovo and the region. While, KFOR sought from protesters and from the Serbian representatives that barricades to be removed with no condition with the purpose to create a normal situation of free movement of people and goods. After the intervention of Brussels, the situation calmed for some days, and KFOR opened some barricades, however, the situation got tensioned on 8 December, where the KFOR forces were attacked by Serbs who reset those barricades again which had been removed once by NATO soldiers.

The crises got deeper when KFOR was provoked by a Russian aid convoy devoted for Serbs, though KFOR in cooperation with EULEX stopped it at the border seeking to control and to associate the convoy, but the Russian ambassador did not accept the control and association of the convoy therefore the crises became deeper and it not only affected the region but also, the relation between Moscow and Brussels. The situation improved after the Russian president had a meeting in Brussels. We may consider that the presence of KFOR in Kosovo is still more than needed, not only to provide peace in Kosovo but also in the region, the extension of the conflict in this region of Kosovo goes even beyond and it is not clear yet how long will it take, as the situation is still in danger, and the region may be associated by projects already declared by Serbia, for the division of Kosovo, therefore until this situation does not change KFOR is still needed in Kosovo. As long as Serbia aims to divide Kosovo, the Security Institutions of Kosovo are in no way capable to install the legal state in the northern part or to prevent any potential conflict or the division of this region. KFOR still remains desirable and more than necessary than any other international mission in Kosovo. The stay of NATO in Kosovo is a strategic need, as it is a strong guarantee for peace, security, stability and democratization of the region. NATO has proved to be as a successful accelerant for the generation of effective multi-national forces, such as SFOR in Bosnia Herzegovina and KFOR in Kosovo, capable of ensuring the implementation of peace agreements and to enlarge the basis for the future stability in regional conflicts in the region of Euro Atlantic.

\section{Conclusions}

Kosovo now for 14 years has a friendly and recommendatory relation with direct and indirect missions that act and support for the most precious part of KSF and the former Kosovo Defense Troops, by directing and orienting in accordance with regulations of NATO Alliance. Kosovo needed and will need the support of this mission, to strengthen and orient our military forces on the best possible way. Fortunately, we can succeed if we will have these missions even in the future in any form or manner in Kosovo, to ensure the stability and modernity moving of Kosovo towards Euro Atlantic structures.

The stay of NATO in Kosovo is a strategic need, as it is a strong guarantee for peace, security, stability and democratization of the region. KFOR is the single force that can guarantee the solution of the inhabited problems in the region.

1 http://diepresse.com/hom/politik/ausseenpolitik/681481/Kosovo Ethenische-Serben-beschiessen-NATO?from=suche.intern.portal 
NATO through its mission KFOR has supported and continues to support the establishment of a long standing peace, the establishment of democratic institutions and creation of interethnic trust as well as to provide a common future for the whole citizens of Kosovo.

\section{References:}

Wesley K. Clark, Waging Modern War, Bosnia, Kosovo, and the Future of Combat Daily "Zëri" Prishtinë 2003

Martti Ahttisari, Duties in Belgrade, Pristine 2008

Enver Bytyqi, The imposing Diplomacy of NATO in Kosovo, The Institute of South East European Studies in Tirana, Tirana 2012

laim King \& Whit Mason, Peace at Any Price How the World Failed Kosovo, Pristine 2007

Bernhard Chiari: Zuruck in den Krieg? Die Unruhen vom Marz 2004, In: Wegweiser zur Geschichte-Kosovo, Herausgegen vom Militargeschichtlichen Forschungsamt, 2006,seite107.

Thomas R. Mockaitis, Civil-Military Cooperation in Peace Operations: The Case of Kosovo, October 2004, Strategic Studies Institute Hom. http://www.carlise.arm.mil/ssi/

OSCE Mission in Kosovo, Kosovo/Kosovo-As Seen, As Told. A Report on the Human

Rights Findings of the OSCE Mission in Kosovo June to October 1999 (Pristine: OSCE Mission in Kosovo 1999)

Has the establishment of Peace Brought change in Kosovo, a study on efficiency of Peace Establishment to Prevent Violence : Lessons learnt from March 2004 riots in Kosovo, the Project for Joint Learning of CDA, July 2006UNSC Resolution 1244, Annex 2.

http://www.ploughshares.ca/libraries/WorkingPapers/wp012.html

http://diepresse.com/hom/politik/ausseenpolitik/681481/Kosovo

Ethenische-Serben-beschiessen-NATO?from=suche.intern.portal

Htpp://www.kosovonews.de/669/kfor

http://www.nato.int/kfor/.com 